\author{
Alicja Żywczok ${ }^{1}$ iD http:/orcid. org/0000-0003-3994-9558 \\ Uniwersytet Śląski
}

\title{
TRWANIE I HUMANIZACJA RODU LUDZKIEGO. RECEPCJA DOROBKU KULTUROWEGO STANISŁAWA WAWRZYŃCA STASZICA
}

\author{
Persistence and Humanization of the Human Race. Reception of the \\ Cultural Output of Stanisław Wawrzyniec Staszic
}

Su m mary: The exceptional position of Father Stanisław Wawrzyniec Staszic in the history of Poland inspires one to reconstruct and interpret his views also in the field of "human philosophy", "philosophy of upbringing" or social philosophy. Not disregarding other works by Staszic, this paper focuses first of all on the contents of Ród ludzki, due to its originality and the possibility of transmitting the cultural capital of the past to contemporary and future recipients of culture. The priority cognitive aim of the author of the article was to obtain significant material for the social and cultural development of mankind, using hermeneutic methods. The research problems were formulated as follows: How does Staszic understand mankind/human race? (or how does he define this notion?); Is it possible, according to Staszic, to humanize mankind?; If so, how does it take place and how does it manifest itself?; What factors of persistence (or, possibly, survival) and what factors of humanization of mankind can be identified?; What, according to Staszic, most seriously impeded these processes in the history of mankind?; What role does he think philosophers, the clergy and pedagogues played in this area?; What message for modern generations can be drawn as a result of the analysis and interpretation of Ród ludzki?

Ke y w o rd s: mankind, human species, Stanisław Staszic, Enlightenment, dignity, the mind, will, freedom

1 Dr hab. Alicja Żywczok, prof. UŚ, Uniwersytet Śląski, Wydział Nauk Społecznych, ul. Grażyńskiego 53, 40-126 Katowice, e-mail: alicjazyw@wp.pl. 


\section{Wprowadzenie}

Dobra znajomość działalności księdza Stanisława Wawrzyńca Staszica (urodził się w 1755 roku w Pile - na terenie dawnego zaboru pruskiego, a zmarł w 1826 roku w Warszawie) pozwala usprawiedliwić nieprzytaczanie w niniejszym artykule wielu faktów biograficznych. Konieczne okazuje się jednak zwięzłe uwypuklenie najważniejszych osiągnięć oraz nakreślenie powodów uznania społecznego okazywanego temu zasłużonemu Polakowi. Jak pisze Witold Molik:

W panteonie wybitnych Wielkopolan Stanisław Staszic zajmuje miejsce wyjątkowe. Nie było bowiem w końcu XVIII i początkach XIX stulecia dziedziny życia publicznego, do której rozwoju nie wniósłby on trwałego wkładu. Zajmował się nauczaniem dzieci pańskich, organizowaniem szkolnictwa oraz rozbudową krajowego przemysłu i górnictwa. Wysuwał jednocześnie projekty reformy ustroju Rzeczypospolitej i prowadził szeroko zakrojone badania naukowe: pisał utwory odnoszące się do aktualnych wydarzeń politycznych, tłumaczył dzieła klasyków starożytnych i myślicieli francuskiego Oświecenia, a także badał strukturę geologiczną ziem polskich i próbował dokonać reformy obowiązującej pisowni. Rozwijał ponadto szeroką działalność filantropijną i interesował się żywo teatrem. Wreszcie u schyłku życia ukończył wielki poemat historiozoficzny, w którym usiłował ukazać wszystkie sprężyny dziejów ludzkości².

Inspiracji do powstania dzieła Ród ludzki dostarczyły Staszicowi zarówno edukacyjne podróże krajowe, jak i zagraniczne, między innymi do Paryża, Wiednia, Lipska, Getyngi, które zapewniły mu poznanie życia intelektualnego znakomitości ówczesnej Europy (między innymi Georges’a Louisa Leclerca - hrabiego Buffon - przyrodnika, matematyka i filozofa francuskiego) oraz zrodziły zainteresowanie historią, filozofią, fizyką i geologią. Epoki natury autorstwa Buffona uznaje się za podwalinę koncepcyjną Rodu ludzkiego.

Dzieło Ród ludzki, pisane przez prawie trzydzieści lat, należy do największych przedsięwzięć literackich i naukowych tego myśliciela. Staszic zaprezentował w nim koncepcję rozwoju ludzkości i narodów oraz mechanizmów rządzących historią. Niestety, lektura tego nieprzeciętnego dzieła wymagała i nadal wymaga dużej cierpliwości oraz koncentracji uwagi ze względu na posłużenie się staropolskim językiem i odautorskimi neologizmami. W rezultacie utwór, w którego napisanie Staszic włożył tyle wysiłku, pozostaje do dziś mało znany, zaś przedstawiona $\mathrm{w}$ nim koncepcja historiozoficzna, będąca jedną z najwybitniejszych w ówczesnej Europie, nie wywarła zamierzonego przez autora wpływu na rozwój

2 Witold Molik, Stanisław Staszic (1755-1826) (Poznań: Krajowa Agencja Wydawnicza, 1980), 5. Zob. też Stanisław Cieszkowski, Stanisław Staszic: filantrop, mąż stanu i uczony ur. 1755-1826. Zarys biograficzny w setna rocznicę zgonu (Warszawa: Biblioteka Domu Polskiego, 1925); Zofia Chyra-Rolicz, Stanisław Staszic (Warszawa: Państwowe Wydawnictwo Naukowe, 1980); Zbigniew Wójcik, Stanisław Staszic. Organizator nauki i gospodarki (Kraków: Stowarzyszenie Wychowanków Akademii Górniczo-Hutniczej im. Stanisława Staszica w Krakowie, 1999). 
nauk. Niewątpliwie odkrywcze poglądy i refleksje Staszica nieco straciły na atrakcyjności ze względu na niezrozumiały język wypowiedzi. W obawie przed cenzurą dzieło swego życia wydał zresztą nielegalnie w latach 1819-1820. Przez blisko dziesięć lat spoczywało ono w ukryciu i dopiero w wyniku przypadkowego odkrycia, zimą na przełomie 1829 i 1830 roku, kilkadziesiąt jego egzemplarzy rozeszło się wśród mieszkańców Warszawy ${ }^{3}$.

Odnośnie do ówczesnego czytelnictwa i percepcji dzieła Ród ludzki wypowiedział się sceptycznie między innymi Bogdan Suchodolski. Oto reprezentatywny fragment:

W wielkim poemacie nadziei, jakim jest Ród ludzki, nad którym pracował niemal całe życie, ukazał, jak się przez wieki dokonywał postęp społeczny. Nie przyjmując łatwej, optymistycznej wiary epoki Oświecenia, iż postęp nauk i publicznej oświaty zbuduje nową, sprawiedliwą epokę dziejów, wyznawał wiarę w skuteczność walki, jaką prowadzili i prowadzą uciskani z ciemiężycielami. I w tych historiozoficznych refleksjach dawał wyraz myślom, które by zdumiały jego współczesnych, gdyby Ród ludzki czytali. I tych konserwatystów, którzy i tak mieli go za fanatycznego wroga przywilejów stanowych i magnacko-szlacheckich tradycji, i tych młodych radykałów, którzy nie chcieli akceptować jego programu „pracy organicznej” i oskarżali go o ugodowość zbyt daleko posuniętą ${ }^{4}$.

Odkrywczość dzieła zatytułowanego Ród ludzki tkwi w trafnej analizie dziejów człowieka na Ziemi, ksiąg historycznych i religijnych, które wytyczyły drogi ludzkości, określiły na setki lat niepodważalne prawdy i zasady moralne. Staszic ukazał reguły i prawa, którymi rządzą się i którym podlegają ludzie, śledząc ich ewolucję od czasów wspólnoty pierwotnej do czasów jemu współczesnych. Przekonywał, że ewolucja ta nie dzieje się samoistnie, że zazwyczaj znajdują się grupy ludzi, które potrafią owe prawa wykorzystać do realizacji swych interesów. Okazuje się, że pomimo upływu czasu ród ludzki podlega wciąż tym samym procesom. Te same prawa i zasady obowiązują dziś, w codziennym życiu, w polityce, oświacie, moralności, w relacjach międzyludzkich. Dzieło Staszica pozwala uświadomić, zrozumieć i poznać mechanizmy, którym zawsze człowiek podlegat ${ }^{5}$.

Nie pomijając innych powszechnie znanych prac Stanisława Staszica, takich jak Przestrogi dla Polski ${ }^{6}$ czy Uwagi nad życiem Jana Zamoyskiego ${ }^{7}$, pragnę

3 Zob. Molik, Stanisław Staszic..., 28, 29.

4 Bogdan Suchodolski, „Wstęp”. W: Stanisław Staszic, Być narodowi użytecznym, wybór Bogdan Suchodolski (Wrocław: Wydawnictwo Stronnictwa Demokratycznego „Epoka”, 1985), 19-20.

5 Zob. Grzegorz Podgórski, „Od wydawcy”. W: Stanisław Staszic, Ród ludzki, www.powrotdonatury.net.pl/...Ród\%20ludzki\%20...\%20Staszic.pdf/download.html, 2-3 (dostęp: 18.05.2019).

6 Zob. Stanisław Staszic, Przestrogi dla Polski, oprac. Stefan Czarnowski (Wrocław: Zakład Narodowy im. Ossolińskich - Wydawnictwo, 2003).

Zob. tenże, Uwagi nad życiem Jana Zamoyskiego, wydanie krytyczne przygotował i wstępem zaopatrzył Stefan Czarnowski (Kraków: Krakowska Spółka Wydawnicza, 1926). 
przeanalizować przede wszystkim zawartość merytoryczną Rodu ludzkiego, dostrzegając oryginalność tego dzieła oraz mając na uwadze przekaz cennego kapitału kulturowego przeszłości (minionych pokoleń) współczesnym i przyszłym odbiorcom kultury.

Pozyskanie dzięki metodom hermeneutycznym (zwłaszcza pól semantycznych oraz interpretacji twórczej: wstępnej, zasadniczej, skoordynowanej; kontekstowej i intertekstowej) ${ }^{8}$ treści znaczących dla rozwoju społecznego i kulturowego ludzkości ${ }^{9}$ stało się priorytetowym celem poznawczym autorki niniejszego artykułu. Zatem problemy badawcze zostały sformułowane następująco:

- Jak Stanisław Staszic pojmuje ludzkość/ród ludzki (i jak definiuje ten termin)?

- Czy, w przekonaniu Staszica, jest możliwa humanizacja ludzkości? Jeśli tak, to jak zachodzi i jak się przejawia?

- Jakie, w myśl autora Rodu ludzkiego, daje się wyliczyć czynniki trwania (względnie przetrwania) oraz humanizacji ludzkości?

- Co stanowiło w dziejach ludzkości, w jego opinii, największe przeszkody w realizacji tych procesów?

- Jaką rolę przypisuje w tym zakresie filozofom, duchowieństwu i pedagogom?

- Jakie przesłanie pedagogiczne dla współczesnych pokoleń udaje się odczytać w wyniku analizy i interpretacji treści dzieł Staszica?

Staszic, choć nie uprawiał filozofii, miał jednak wyraźne przekonania filozoficzne - i dawał tym przekonaniom niejednokrotnie wyraz bezpośrednio bądź pośrednio. Wyjątkowa pozycja Staszica w dziejach Polski sprawia, że warto rekonstruować ${ }^{10} \mathrm{i}$ twórczo interpretować jego poglądy również z zakresu „filozofii człowieka”, „filozofii wychowania” czy filozofii społecznej.

${ }^{8}$ Zob. Jean Grondin, Wprowadzenie do hermeneutyki filozoficznej, tłum. Leszek Łysień (Kraków: Wydawnictwo WAM, 2007); Antoni Stępień, Wstęp do filozofii (Lublin: Towarzystwo Naukowe Katolickiego Uniwersytetu Lubelskiego, 2001); Bogusław Milerski, Hermeneutyka pedagogiczna. Perspektywy pedagogiki religii (Warszawa: Wydawnictwo Naukowe ChAT, 2011); Wartość i sens. Aksjologiczne aspekty teorii interpretacji, red. Andrzej Tyszczyk, Edward Fiały, Ryszard Zajączkowski (Lublin: Wydawnictwo Katolickiego Uniwersytetu Lubelskiego, 2003).

${ }^{9}$ Por. Alicja Żywczok, „»Ludzkość« - zapomniana kategoria nauki. Batalia o przypomnienie i włączenie terminu do programów edukacyjnych". W: Pedagogika filozoficzna, t. 7: Uniwersalizm i regionalizm pedagogiki filozoficznej, red. Sławomir Sztobryn, Dariusz Stępkowski (Łódź: Wydawnictwo Naukowe TPF „Chowanna”, 2017), 17-29.

10 Zob. Jacek Jadacki, „O poglądach filozoficznych Stanisława Staszica”, Rocznik Towarzystwa Naukowego Warszawskiego 68 (2005), 29. 


\section{Nierozpoznany i niepozyskany potencjał tkwiący w ludzkości - najważniejsze założenie myśli reformatorskiej Staszica}

Staszic, doceniając szlachetność rodu ludzkiego (uważał, że zaszczytem jest zostać zrodzonym jako członek tego rodu), był przekonany o wielkim, nieodkrytym potencjale tkwiącym w społeczności powszechnej, za jaką uważał ludzkośćc ${ }^{11}$. Zaakcentował szczególne przymioty człowieka, takie jak rozum czy wola, predysponujące go do pragnienia wolności i rozszerzania zakresu wolności własnej (czyli wyzwalania się) i innych ludzi (czyli oswabadzania ich, wyprowadzania z wszelkiej niewoli). Wspomina również o granicach wolności, zwłaszcza konieczności samoograniczenia jej dla dobra wspólnego, oraz o ścisłym związku wolności ze sprawiedliwością. Nie pomija również opisu znaczenia uczuć (według Staszica - „czucia”), decydujących o wrażliwości emocjonalnej i moralnej, więc także konstytuujących istotę ludzką.

Kwestię szlachetności (niemal doskonałości) człowieka podejmuje w dziele Ród ludzki (w wersji elektronicznej - tekst oryginalny został nieznacznie zmodyfikowany językowo przez językoznawców w celu komunikatywności i uprzystępnienia treści odbiorcy ${ }^{12}$ ), pisząc:

Między wszystkimi stworzeniami najdoskonalszy jest rodzaj ludzki. Na ostatku Bóg stworzył człowieka. W nim zakończył swoje dzieło; w nim połączył wszystkie stworzenia tej ziemi z Zamiarem [celem ostatecznym - A.Ż.] całego świata. Wielkiej rodzajowi ludzkiemu nadał własności do dążenia do wielkiego Zamiaru, niżeli tej ziemi, z której się ludzie żywią. Między rodzajem ludzkim i między tym światem i sobą

11 Staszic wprawdzie nie zdefiniował terminu „ludzkość”, jednak treść dzieła Ród ludzki dostarcza wyjaśnień pozwalających wnioskować, iż ludzkość pojmował jako:

- „zjednoczenie wszystkich ludzi na świecie”. Staszic, Ród ludzki, 35 (dostęp: 18.05.2019). Zob. też tenże, Ród ludzki, t. 1-3 (Warszawa: Państwowe Wydawnictwo Naukowe, 1959).

- sumę pokoleń przeszłych i teraźniejszych. Potwierdza to następujący fragment: „Skąd wzięły się te niezliczone pokolenia? Zmienił się pierwszy tej ziemi człowiek, już odmieniła się i pierwsza tej ziemi postać. Już to nie jest owo jakby obłąkane jestestwo. Jest to szanowany rodzaju ludzkiego ojciec. Otaczają go niezliczone pokolenia ludzi. Wszystkie w nim swój początek biorą i wszystkie, nawet najodleglejsze, w nim się łączą". Tamże, 26.

- sumę rodów, czyli familii (dziś - rodzin). Wyjaśnienie to dotyczy (synonimu terminu „ludzkość”) „rodu ludzkiego”. Na ród ludzki składałyby się więc wszystkie rody świata. Tamże, 27, 28.

- zrzeszenie narodów. To rozumienie odnosi się jedynie do kontekstu językowego, w którym „ludzkość” nazywa Staszic „narodem ludzkim”. Tamże, 18, 210.

12 W przypadku fragmentów dzieł Stanisława Staszica sprawiających dziś trudność w ich zrozumieniu (bądź jednoznacznym zrozumieniu) autorka artykułu podaje w nawiasach współczesne synonimy niektórych słów, które z biegiem czasu albo wyszły z użycia, albo stanowią neologizmy, albo też kwalifikują się do drobnych błędów językowych. W miejscach niejasnych autorka wprowadza w nawiasach słowa pozwalające utrzymać ciągłość językową rekonstruowanej myśli Staszica. 
największe położył związki. Człowieka najściślej złączył ze sobą. Uczynił go na swoje podobieństwo $^{13}$.

W opinii Staszica człowiek pozostaje nie tylko najdoskonalszym stworzeniem Boga, ale istotą najsilniej związaną ze Stwórcą i do Niego podobną.

Staszic dokonał deskrypcji zasadniczych przymiotów człowieka, uznając je za przejaw stwórczej celowości. Twierdzi, iż Bóg:

[...] tchnął w niego promień światła nieśmiertelności, aby poznawał związki swoje z wszelkim stworzeniem na tej ziemi i związki tej ziemi z innymi światami, ze słońcem; aby miał wolność wybierania między nimi, umniejszał sobie szkodliwe, a pomnażał swoje stosunki z tymi, które uzna za sposobne do powiększania szczęśliwości swojej, to jest które ułatwiają mu wykonanie ustawy natury, a [...] razem z nim zrządzają stosunek tej ziemi z wielkim porządkiem wszystkich światów [...]. Tak: człowiek jest najprzedniejszą sztuką tego niepojętego dzieła [stworzenia - A.Ż.] [...]. Bez człowieka jest to dzieło niezakończone. Tylko rodzajowi ludzkiemu Bóg wyznaczył całą ziemię. Wszystkie kraje tego świata są krajem plemienia człowieka. Z wszystkich stworzeń tylko jednemu - rodzajowi ludzkiemu udzielono tę własność, iż żyje i mnoży się tak na północy, jak na południu. On jeden otrzymał cząstkę władzy samego Bóstwa nad materią, to jest rozum. Z tą niepojętą własnością nie jest jak inne stworzenia koniecznie przymuszony być tylko w pewnym miejscu, nie jest koniecznie zawisły tylko od pewnych stosunków i tylko od pewnych jestestw. On jeden jest wolny. On jeden ma wolę wybierania sobie między nieskończonymi stosunkami i między niezliczonymi rzeczami. Czuje i odbiera swoje związki z rzeczami bliskimi sobie jak z najodleglejszymi jestestwami, stosuje do siebie rzeczy teraźniejsze i jeszcze pomniejsza albo powiększa swoje stosunki z tymi, które dopiero istnieć będą. Wprowadza nowy porządek między rośliny i zwierzęta, jedne wytępia, drugie rozmnaża [...]. Wszędzie podług związków tej ziemi ze słońcem stanowi [ustanawia - A.Ż.] między ziemią i jej rodzajami porządny stosunek. Owszem, nadaje [jej - A.Ż.] nowy kształt i postać: góry zniża, doły wywyższa, skały kruszy albo żyzną ziemią okrywa; wody osusza, rzekom drogi wyznacza; morzu granice kładzie. Zgoła całą ziemię w urodzajną zamienić stara się, a coraz obszerniej po niej swój rodzaj rozmnażając, upowszechnia rozum, to jest swojego rodzaju nad materią władzę i moc. Stanie się: będą mu posłuszne i żywioły [...], będzie sprowadzał i będzie oddalał podług swojego użytku ognie, deszcze i wichry. Po Bogu najwyższą władzą na tej ziemi jest powszechny rozum ludzkiego rodzaju. Przed nim gnie się cała natura [...]. Ludzie [są - A.Ż.] końcem powszechnej szczęśliwości; im więcej odkrywają związków z rzeczami stworzonymi, to jest im więcej upowszechniają rozum ${ }^{14}$.

13 Staszic, Ród ludzki, 17 (dostęp: 18.05.2019).

14 Tamże, 17, 18. 
Człowiek, w myśl stanowiska Staszica, pozostaje najwspanialszym wytworem twórczego dzieła stworzenia, bytem szczęśliwym, który dba o porządek i przetrwanie świata ${ }^{15}$.

W innym miejscu tego fascynującego dzieła (Ród ludzki) czytamy:

Rozum jest oddzielony od woli. Razem dał ci Bóg rozum i wolę. Doskonałość potrzebuje wolności. Ty siebie doskonaląc masz pomnażać szczęśliwość rodzaju ludzkiego, a on ze swoją powszechną szczęśliwością ma doskonalić i prowadzić tę ziemię do jej Zamiaru. Na to Bóg stworzył cię człowiekiem wolnym. Ale ta wolność ma granice. Ty sam jesteś istotą skończoną. Nie zapominaj, żeś stworzenie, iż żyjesz w świecie pomnymi ustawami rządzonym. Więc jesteś koniecznie zawisły [...]. Więc podlegasz ustawom, pod którymi ten świat stworzony. Doskonalisz się, im dokładniej te ustawy, te prawa wypełniasz. Powiększasz twoją wolność, im więcej do ich wypełniania poznajesz sposobów ${ }^{16}$.

Miernikiem dojrzałości człowieka zdaje się więc, podążając za myślą Staszica, zarówno rozszerzanie zakresu i metod korzystania $\mathrm{z}$ wolności niezbędnej do optymalnego funkcjonowania, jak i umiejętność ograniczania siebie (ascezy) w stosowaniu wątpliwych pod względem moralnym czy społecznym ofert wolnościowych, a raczej pseudowolnościowych, których dziś, niemal dwieście lat po śmierci Staszica, nie brakuje, a liczne okazują się wyjątkowo zwodnicze.

„Na czele ustaw człowieka to stoi: rodzisz się pośrodku światów. Posłuszeństwo Bogu jest twoją wolnością"17 - Staszic kontynuuje myśl dotyczącą osiągania wolności. A w innym miejscu próbuje zdystansować się od terminu „wolnośćc i zdobyć się na odwagę krytycyzmu:

Wolność, słowo pełne obłąkań [pułapek - A.Ż.]. Najwięksi rodu ludzkiego tyrani najwięcej wykrzykiwali: wolność! Grecy, Rzymianie, którzy najgorliwiej czcili wolność, którzy najwięcej o niej mówili i pisali, ciż Grecy i Rzymianie byli największymi rodu ludzkiego gwałcicielami. Milionami więcej od siebie liczyli ilotów, niewolników, ludzi porównanych z bydlętami [traktowanych jak bydlęta - A.Ż.]. Dumni z wolności Anglicy miliony ludzi ujeńczają [biorą w niewolę, uciskają - A.Ż.], którzy nędznie żyć i umierać muszą w okrucieństwie, w pracy dla nasycenia nienasyconej duszy kupców z Indyjskiej Kompanii, możnowładców, którzy dla utrzymania ducha wyłączności, a tym samym niewoli w handlu, burzą świat, rozbili Indie, $\mathrm{z}$ wojen $\mathrm{w}$ wojny pchają Europę. Szlachta niemiecka i szlachta polska, która nazywała wolność „złotą”, była

15 Kontynuację tego poglądu czytelnik może odnaleźć w innym dziele Staszica, w którym zaznaczył, że „Człowiek do opatrywania swoich potrzeb koniecznych ma w całej naturze dwa tylko sposoby: ziemi urodzaje i swój przemysł". Stanisław Staszic, Uwagi nad życiem Jana Zamoyskiego (Wrocław: Zakład Narodowy im. Ossolińskich - Wydawnictwo, 2005), 99. Por. Stanisław Staszic. Geologia - górnictwo - hutnictwo, red. Antoni Stanisław Kleczkowski (Warszawa: Wydawnictwa Geologiczne, 1979).

16 Staszic, Ród ludzki, 18 (dostęp: 18.05.2019). Zob. też Janina Kostkiewicz, Wychowanie do wolności wyboru. Ponadczasowy wymiar pedagogiki Fryderyka Wilhelma Foerstera (Kraków: Oficyna Wydawnicza „Impuls”, 2008).

17 Staszic, Ród ludzki, 19 (dostęp: 18.05.2019). 
wyłącznie samowładna i patrzyła obojętnie na miliony u siebie ludzi bez własności, bez ziemi, bez sprawiedliwości, bez prawa [...]. W wyobrażeniach epoki, kiedy już konstytucyjne nastają towarzystwa i rządy, powszechna dla wszystkich sprawiedliwość jest tym, co prawdziwie powinna znaczyć wolność. Tam, gdzie każdy człowiek $\mathrm{w}$ towarzystwie żyjący staje się przed prawem $\mathrm{z}$ drugimi równy, tam jest sprawiedliwość i tam prawdziwa wolność [...]. Ludzie! Strzeżcie się więc [...] latać za tak zwodniczym, tak [...] oszustwu i twardej osobistości usłużnym słowem „wolność, lecz postępujcie w doskonaleniu [...] towarzystw do ustanowienia powszechnej, dla wszystkich równej sprawiedliwości, bo ona jest obywatelską wolnością ${ }^{18}$.

Choć trudno przypisać myślicielowi niedocenianie wolności (apoteoza wolności w kraju, który utracił niepodległość, była uzasadniona), akcent kładzie jednak na uwzględnianie poczucia sprawiedliwości oraz na proces doskonalenia społecznego i samodoskonalenia, ponieważ bez nich nawet najszlachetniejsze tendencje wyzwoleńcze nie przyniosą oczekiwanych rezultatów inkluzyjnych. Człowiek nie dziedziczy doskonałości, jak twierdzi reformator, zatem zbliżenie się do niej wymaga starań oraz wysiłku indywidualnego, podejmowanego choćby w trakcie procesu wychowania. Proces ten powinien tworzyć warunki raczej do wyzwolenia (względnie wyzwalania) człowieka niż do utraty poczucia wolności.

Z kolei na temat okoliczności utraty wolności oświeceniowy myśliciel wypowiedział się tak: „Człowiek trzema sposobami traci swoją wolność i staje się nieszczęśliwy: albo umniejszaniem tych własności, które mu Bóg nadał, albo przywłaszczaniem sobie własności nadprzyrodzonych, albo błądzeniem w wyobrażeniach przy wybieraniu sposobów do wypełniania ustaw natury. Pierwszy staje się niewolnikiem, drugi czyni się tyranem, trzeci człowiekiem niedoskonałym"19. W przekonaniu Staszica trzy postawy powodują oddalenie się człowieka od szansy osiągnięcia zarówno wolności, jak i szczęścia:

- postawa braku wdzięczności: niedocenianie darów (takich jak ludzkie atrybuty) otrzymanych od Boga;

- postawa pychy: próba „czynienia siebie bogiem”;

- postawa zagubienia moralnego związana $\mathrm{z}$ wyborem niewłaściwego kierunku postępowania.

Staszic podkreśla również doniosłość przeznaczenia człowieka oraz inne (oprócz dążenia do wolności i sprawiedliwości) istotne jego przymioty, takie jak dzielność czy godność. Wspomina o nich w następującym fragmencie:

Naród [ród - A.Ż.] ludzki jest najdzielniejszym narzędziem Opatrzności. Naród [ród - A.Ż.] ludzki swojej powszechnej szczęśliwości szukając ma prowadzić tę ziemię do zamierzonego jej celu [...]. Człowieku, znaj swoją godność, miej zawsze przed oczyma twojego przeznaczenia wielkość. Brzydź się podłością, a umieraj, gdy masz żyć w niewoli. Nad rodzaj ludzki nie ma szlachetniejszego. Ten, kto się nad plemię

18 Tamże, 204.

19 Tamże, 19-20. 
człowieka wynosi, jest nieprzyjacielem twoim i Boga, burzycielem ziemi. On niszczy ten Zamiar, które sobie założyło w rodzaju ludzkim stwórcze Bóstwo [...]. Tobie wyznaczone jest być człowiekiem. To jest twoje miejsce na tym świecie. Tylko w istocie człowieka jesteś sposobny do wykonania Zamiaru twojego Stwórcy. W innym stanie [...] więcej szkodzisz niżeliś na tym świecie użyteczny ${ }^{20}$.

Przymioty, o których mowa, w przekonaniu Staszica nie powinny rodzić w człowieku pychy, lecz skłaniać go do uzasadnionej dumy z człowieczeństwa, motywować do pokornej pracy nad sobą i poświęcenia na rzecz innych ludzi. Człowiekowi jako „najdzielniejszemu narzędziu Opatrzności” przystoi więc brzydzić się złem i niegodziwością (podłością). Myśl ta wzbudza refleksję również odnośnie do losów narodu polskiego; ten zbyt długo znajdował się w niewoli, ciemiężony przez inne narody, by Polacy mogli pozwolić sobie na zaniedbania w zakresie kontynuacji dziedzictwa chrześcijańskich wartości i cnót.

„Dotąd wszystkich narodów historia jest [...] zbieraniną dat: roku, miesiąca, dnia rodzenia, żenienia, kłócenia się i śmierci pewnych osób" ${ }^{\prime 2}$, nie bez racji twierdzi Staszic. Jednak historię można postrzegać również jako dzieje zaprzepaszczania wartości i cnót, dzieje zaniedbań moralnych i rozpanoszenia się przywar/wad narodowych (o problemie wspomnę jeszcze w kolejnej części tekstu), nieprawych przyzwyczajeń oraz haniebnych tradycji (na przykład obyczajów), a także wadliwego procesu wychowania. Historii przypisał Staszic znaczny wkład w „uspołecznianie” rodu ludzkiego, przekonując potomnych, że w dogłębnym poznaniu historii: „[...] dziejopisarz znajdzie rzeczywistą wzrostu, upadku, zguby narodów przyczynę. To jest prawdziwa historia narodów. Ona [...] być może użyteczną nauką. Takie ciągłe śledzenie działań narodowych naprowadzi historię na drogę wielkiej, może najużyteczniejszej umiejętności uspołeczniania rodu ludzkiego"22.

Niech to zagadnienie stanowi element łączący już z kolejną częścią artykułu, dotyczącą proponowanych przez Staszica innych jeszcze (poza znajomością historii) metod „uspołeczniania” i humanizacji ludzkości.

\footnotetext{
20 Tamże, 18.

21 Tamże, 207.

22 Tamże, 207-208.
} 


\section{Powszechny respekt wobec potrzeb człowieka, praw, zasad i opinii publicznej jako skuteczne metody rugowania przywar oraz „uspołecznienia” ludzkości}

Do prawa naturalnego Stanisław Staszic zaliczył proces jednoczenia się ludzi tworzących przeróżne grupy, familie, związki, stowarzyszenia, sojusze itd. Początki ludzkiego rodu, a zgodniej z ówczesną konwencją językową - „poczęcie rodzaju ludzkiego" - wiązał Staszic właśnie z tym procesem. Myśl tę wyraził, pisząc:

Tak pierwszym i najprostszym ustaw natury skutkiem jest stowarzyszenie rodzaju $[\ldots]$, same pierwsze potrzeby sprowadziły w jedno miejsce dwie pierwsze osoby na tej ziemi [...]. Tak począł się rodzaj ludzki, tak urobiło się to pierwsze ogniwo, z którego miał się rozciągnąć $[. .$.$] łańcuch niezliczonych związków, które pierwszych naszych$ rodziców z nieskończonym ich pokoleniem, a to pokolenie, czyli ród ludzki z niezmierną naturą wiązać będą [...]. Wkrótce otoczyły ich dzieci. Te najprzód [wpierw A.Ż.] przez swoją słabość i przez swoje cierpienie, dalej udzielaniem i odbieraniem wzajemnego czucia [uczuć - A.Ż.] ze sobą matkę i ojca wiążąc, umacniały coraz bardziej między nimi te związki, których owocem były ${ }^{23}$.

Z kolei:

[...] rodzaj dzieli się na osobne familie, familie dzielą się odległym miejscem, ale wszystkie i wszędzie jedną ludzkość czując, nigdzie nie dzielą się rodzajem [...]. Jaka w każdej familii wewnętrzna spokojność! Jaka wszędzie czułość na każdy krzyk boleści lub gwałtu w którymkolwiek pokoleniu! Tu zadziwia to ślepe zaufanie i posłuszeństwo dzieci do rodziców i do każdego starszego. Cieszy ta nieustanna trwożliwość rodziców i starszyzny o ubezpieczenie życia dzieci i wszelkiej bezsilnej młodzi²4.

Artykulacja ludzkich praw i potrzeb, obowiązków rodziców względem potomstwa, więzi uczuciowej w pierwszych rodzinach służy zwróceniu uwagi na początki rodu ludzkiego i podstawowe warunki jego ewolucji społecznej. Respekt wobec prawa naturalnego i potrzeb ludzkich (wśród których dominowały potrzeba miłości, bezpieczeństwa i przynależności) miał zapewniać pierwszym ludziom życie we względnej harmonii i zgodzie. W celu przybliżenia postrzegania przez Staszica relacji panujących w początkowych okresach istnienia ludzkości warto przytoczyć wiernie odpowiedni fragment dzieła:

We wszystkich pokoleniach płeć słaba używa zupełnej wolności naturalnej. Nigdzie moc męża nie budzi się na jej krzywdę, lecz na jej obronę. Człowiek natury jest każdego człowieka bratem, jeszcze ich dział własności nie niechęci. Natura kładzie nieskończone między nimi związki [...]. Chciwość, pycha, zawziętość, rozwiązłość, niewola

\footnotetext{
23 Tamże, 22-23.

24 Tamże, 27.
} 
nie dręczą w nim serca i nie wydzierają mu jeszcze ani dnia, ani nocy [...]. Tym dzikim a szczęśliwym ludziom jeszcze ani żaden oszust, ani oszczerca, ani żaden prawodawca innych praw nie daje. Tych familii a pierwszych ludzkich towarzystw zasadami i prawem są same ustawy natury [...]. Ojcowie i synowie równie prawu być posłuszni muszą [...]. Nie ma tu wyjętych prawem od słabości dzieciństwa do niedołęstwa starości. Prawa nie przyznają jednym dziedzictwa doskonałości [...] i mocy, a drugim dziedzictwa [...] hańby swoich ojców [...]. Nie rodzą się poczciwi i niepoczciwi, panowie i niewolnicy ${ }^{25}$.

A nieco dalej autor dzieła jasno zaznaczył, że „Stróżem praw natury jest ojciec, ale stróżem sprawiedliwości ojców jest powszechna ludzkość"26. Ze słowem i decyzją ojca liczyli się wszyscy domownicy. Opinia wyrażana w rodzinie przez ojca stanowiła pierwowzór zarazem opinii społecznej i kontroli społecznej.

Znamienne w powyższej wypowiedzi jest również to, iż określając „rodowód” nieszczęść ludzkości, wiąże je z terminem „dzierż”, to znaczy z własnością i nierównościami w zakresie nabytej na różne sposoby własności. Ta poróżniała ludzi i stawała się przyczyną niepokoju, waśni i wojen. „Myśl o własności nie ma granicy. Ile potrzeb naturalnych czuje człowiek, tyle wkrótce zaliczy sobie własności. Każda własność krzywdą innych części ogółu będąc [...]. Człowieku właścicielu! [...]. Duch prawej własności miał prowadzić [cię - A.Ż.] za prawdą"27 - sugestywnie apeluje myśliciel do czytelników, nie ukrywając swego rozczarowania postępowaniem człowieka w dziejach.

Jak się okazuje, ludzkości w każdym okresie dziejów zagrażały te same niebezpieczeństwa. Oprócz nieszczęść naturalnych, tak zwanych zewnątrzpochodnych (takich jak klęski żywiołowe, plagi, choroby, kataklizmy), niemałe zagrożenie tworzyły przyczyny wewnątrzpochodne, choćby ludzkie przywary, zwłaszcza chciwość, zazdrość, zawiść, gdyż stawały się przyczyną tarć, walk i wojen. Groźne w skutkach okazywały się również pycha (związana z nadmierną ambicją) i lenistwo, gdyż cechujący się nimi ludzie, przejawiając poczucie wyższości („chęć rozkazywania naturze”) oraz niechęć do wysiłku, byli skłonni do bezlitosnego zawłaszczania cudzych dóbr (nazywanego grabieżą).

Staszic pisze: „Z myśli nierządnej własności wywinęły się dwie żądze najgłówniejsze: chciwość i ambicja [...]. Przez nie człowiek silny może stać się dobrodziejem i obrońcą innych, ale również zabójcą i tyranem”28. Jednak „rzadko który szlachcic ma tyle mocy nad swoją chciwością, aby, nie mogąc wszystkich, nie uciemiężał tych więcej, którzy się lepiej mają”29. Oprócz tego „Fałszywe wyobrażenie bogów skaziło rozum i uczyniło człowieka zabobonnym i bałwochwalcą. Dzierż [własność - A.Ż.] skaziła w nim czucie ludzkości i uczyniła

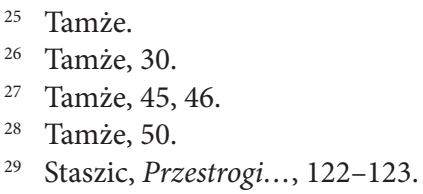


człowieka okrutnym"30, słusznie twierdzi oświeceniowy myśliciel. Przyczyną wielu nieszczęść stał się również irracjonalny strach. Staszic zaobserwował bowiem, że „bojaźń dzielniejsza jest w ludziach niż nadzieja” ${ }^{31}$. Poddał krytyce także inne przywary, które zaobserwował wśród swych rodaków, między innymi obżarstwo i pijaństwo, poświęcając wiele miejsca kwestii zachowania umiaru w jedzeniu oraz trzeźwości, tak w narodzie, jak i poza nim.

Nie pominął wojny jako przyczyny wszelkich nieszczęść i nieprawości (dziś powiedzielibyśmy - dehumanizacji). Wspomina o niej następująco: „Między głównymi rodzajami ludzkiego nieszczęścia kładą wojnę. Wszyscy w codziennych modłach proszą Boga, aby ich wybawił od wojny [...]. Królowie! Przestańcie wojen [...]. Wszelka nieprawość ma swoją miarę"32. Wojna domowa czy międzynarodowa, wbrew powszechnemu sądowi, „nie zasadza się na męstwie, ale na sztuce [wojowania - A.Ż.] i pieniądzach"33. Oto dodatkowe argumenty odsłaniające prawdę o genezie wojen, a jednocześnie wzmacniające nastawienie pokojowe ludzi na świecie.

Nowatorskim osiągnięciem myśli Staszica było bez wątpienia odsłonięcie dobrodziejstw opinii powszechnej (dziś - opinii publicznej). Zaznacza:

Czym jest rozum w człowieku, tym jest opinia w rodzaju ludzkim. Co obraża ją, to obraża ludzkość. Wszystkie wzruszenia [poruszenia - A.Ż.] opinii są wzruszeniami ludzkości. Lecz potężna opinio! Twój początek jest dziki. Oto dziki pasterz i dziki łowca zakładają początki twojego jestestwa. Rozum człowieka, jeszcze pełen omamień zmyślnych i urojeń imaginacji i snów, jest twoim stwórcą. Tylko ten rozum człowieka doświadczeniem oświecony może ci nadawać wzrost i światło [...]. Kiedy przez wolność ułatwisz doświadczenie i wzrost rozumu człowieka, ułatwisz swój własny wzrost [...]. Istotne związki przyrodzonych rzeczy z człowiekiem powinny być twoją zasadą. Natenczas moc człowieczeństwa przez ciebie rządzona będzie niszczyć szkodliwe, a obierać stosunki użyteczne [...], a własność poda mu sposoby nieskończone do przeistoczenia natury w jestestwa ludziom użyteczne ${ }^{34}$.

Oprócz znaczenia pozytywnego, jakie przypisuje opinii powszechnej, Staszic dostrzega również jej niewątpliwe zagrożenia. Swym przewidywaniom daje wyraz w następującym fragmencie: „O niezbędna opinio! Ty stworzysz i przedłużysz wiek barbarzyństwa. Człowiek będzie [...] lękać się myśleć, będzie mieć ludzkość [człowieczeństwo - A.Ż.], ale czuć jej nie będzie zabijając ludzi, układając gwałt i zdradę narodów [...]. Taka to opinia poczyna się w tej dziczy. Z opinią wszczyna się nieszczęsna ambicja, czyli nienasycona żądza zjednania sobie opinii. Tu początek nadwątlenia ludzkości [...]. Opinia powszechna tworzy obyczaje

\footnotetext{
30 Tenże, Ród ludzki, 111 (dostęp: 18.05.2019).

31 Tamże, 58.

32 Staszic, Przestrogi..., 31, 33, 34.

33 Tamże, 186.

34 Staszic, Ród ludzki, 69 (dostęp: 18.05.2019).
} 
powszechne [...]. Wprowadzi w narody podłość i fałszywość”35, zrodzi bojaźń [strach, niepokój - A.Ż.] i nieszczerość, a zniesie zaufanie ${ }^{36}$.

Do jakich rozmiarów rozrosły się opisywane przez oświeceniowego myśliciela wypaczenia opinii powszechnej - daje się współcześnie zaobserwować, śledząc na przykład wydarzenia publiczne komentowane w środkach masowego przekazu. Jak trafna okazała się wizja zmniejszenia zaufania społecznego, za to zwiększenia nieszczerości, manipulacji i strachu, można przekonać się niemal każdego dnia prawie w każdym zakątku świata.

W przekonaniu Staszica-historiozofa „uspołecznienie ludzkości”, a tym samym oczekiwana humanizacja, może nastąpić tylko w wyniku doskonalenia moralnego jednostek za pośrednictwem respektowania wspomnianych czynników: wartości (zwłaszcza społecznych i moralnych), prawa naturalnego, zasad współżycia społecznego, prawidłowej obyczajowości (tu - „obyczajności”), opinii powszechnej i religii. Na bazie prawa naturalnego społeczności wypracowały prawo stanowione, a także w szerszym zakresie dopuściły do głosu opinię społeczną, postrzegając je jako powstrzymujące eskalację ludzkich przywar.

\section{Propagowanie postawy przychylności wobec rodu ludzkiego jako wyzwanie dla filozofów i duchowieństwa, a jej wychowawcze kształtowanie - zadanie pedagogów}

W charakterystyce optymalnej postawy człowieka wobec "rodu ludzkiego” warto korzystać z dziedzictwa Stanisława Staszica, gdyż optykę, którą reprezentował ten reformator społeczny i oświatowy epoki Oświecenia, można dziś określić „liczeniem się człowieka jako jednostki z ludzkością” bądź „uwzględnianiem w postępowaniu człowieka dobra ludzkości”. Pisze: „Nie tylko utrzymywać życie własne, ale musi każdy człowiek pomnażać plemię własne. Uczucia jednego człowieka będą mogły poruszać zmysły człowieka drugiego i budzić w nim stosowne do siebie uczucie. Boleść cierpiącego człowieka powinna wzruszać w drugim człowieku boleśćn" ${ }^{37}$.

Specyficzne cechy postawy przychylności wobec ludzkości najlepiej odsłania fragment dzieła:

O gdyby samą miłość rodu ludzkiego tchnąć, stale tylko tego uczyć, że wszyscy ludzie są równi, wszyscy są braćmi, żaden nie może mieć więcej przywilejów od drugich, każdy powinien kochać każdego bliźniego jak siebie samego - bylibyście dobroczyńcami ludzkości, a nie byłoby zapewne na tej ziemi ani tyraństwa, ani niewoli. Wieleż

\footnotetext{
35 Tamże, 70.

36 Zob. tamże.

37 Staszic, Przestrogi..., 19.
} 
to wojen, rzezi i krwi bylibyście oszczędzili? Wiele tysięcy narodów zachowali, które zagubiły się okrutnie albo nie ukazały się nawet? Przekonacie się, że ci przyłożyli się do nieszczęśliwości naszego rodzaju, którzy spomiędzy was zamiast otwartości braterskiej powlekli w tajemnicze ciemności i swój stan, i swoją naukę, i oddzielili się najpierw od ludzi, przywłaszczając sobie moc nadludzką przestawania z bogami, poznawania przyszłości, rozdawania niewinności i przekleństwa, zbawienia i wiecznej zguby [...]. Jednym zapewnili wieczne panowanie, drugim nieskończone poddaństwo i niewolę. Stworzyli nierówność i zerwali wszystkie między człowiekiem a człowiekiem odwieczne związki [...]. Filozofowie, cierpiąca ludzkość do was o ratunek wzdycha ${ }^{38}$.

Inne składniki analizowanej postawy wobec ludzkości opisuje Staszic następująco:

Zapominam urodzenie moje, nie mam stanu, nie jestem obywatelem żadnego kraju, otrząsam z usilną pracą mój rozum z wszystkich przesądów, jeden już tylko w moim sercu głos słyszę, że jestem człowiekiem, a ci, co cierpią, moimi bliźnimi. Z tym czuciem [...] jednym okiem obejmuję całą ziemię. Trzech części ludzkości staję się obrońcą, czwarta część jest stroną przeciwną, a cały ród ludzki będzie sędzią. Człowieku! W którejkolwiek stronie tej ziemi mieszkasz, w którymkolwiek kraju obywatelem albo poddanym, czyli niewolnikiem żyjesz, którąkolwiek czcisz religię, równie cię kocham. Poznaj twoje prawo i twój obowiązek. Umiej się odtąd więcej poważać i przestań cierpiećs $^{39}$.

Wyjaśniając szczegółowe komponenty postawy wobec ludzkości, Staszic nie proponował pomijać swego rodowodu czy miłości do ojczyzny, ale zwrócił uwagę, iż ta ostatnia nie powinna stanowić przeszkody w uogólnieniu przychylności na wszystkich ludzi. Ani status społeczny, ani wyznanie nie powinny przysłaniać człowiekowi w miarę obiektywnego postrzegania drugiego. Warto przy tym chronić się przed niebezpieczeństwami postawy polegającej na zakrywaniu swych niegodziwości argumentem działania dla dobra ludzkości. Wątpliwe jest również to, czy człowiek deklarujący służbę ludzkości, a niezauważający potrzeb swej matki lub sąsiada przysłuży się ludzkiemu rodowi. Kreowanie zbliżonego pozytywnego stosunku do społeczności lokalnej i globalnej, pozbawionego przesądów bądź uprzedzeń, stanowi wymóg człowieczeństwa oraz humanistyczną „inwestycję" w teraźniejsze i przyszłe istnienie ludzkości.

Swój apel kieruje również do duchowieństwa, pisząc:

[...] przezacne duchowieństwo! Ty jesteś tłumaczem tych praw, które Bóg każdemu człowiekowi oddał, które mają człowieka zbliżyć do człowieka - nie czynić go uciemiężycielem ludzi albo nieprzyjacielem plemienia ludzkiego. - Kochaj twojego bliźniego, jak siebie samego, a Boga nad wszystko [...]. W ogłaszaniu tej prawdy nic

38 Tenże, Ród ludzki, 2, 7 (dostęp: 18.05.2019).

39 Tamże, 6, 7. 
was fałszywymi czynić nie powinno, ani bogactwa, ani godności, ani śmierć sama. Mówcież więc do Polaków, że ten nie jest chrześcijaninem [...], kto z jakiejkolwiek przyczyny zaprzecza [odmawia - A.Ż.] drugiemu człowiekowi sprawiedliwości [...], wolności przyrodzonej i własności. Jeżeli nauczacie inaczej, nie uczniami Chrystusa, ale zdrajcami rodzaju ludzkiego jesteście. Jeżeli pod najświętszym imieniem Jezusa, łakomcy, oszczercy, dumni, usprawiedliwiacie człowieka niewolę, oto słuchajcie i zadrżyjcie [...]. Powołanie wasze jest, abyście byli obrońcami prawdy na ziemi, abyście z ofiarą życia stawali przy ludziach przeciwko gwałtownikom, abyście gromili tyranów, którzy by obdzierali człowieka z tych darów, które mu Bóg nadał ${ }^{40}$.

Adresatami charyzmatycznych słów Staszica są także pedagodzy. Świadczy o tym jedna z wypowiedzi:

[...] najużyteczniejsi w kraju nauczyciele Edukacji Publicznej [...]. - Jeżeli te prawdy ode mnie wyrzeczone padną nieużytecznie na umysły zastarzałych w uprzedzeniu, w złym wychowaniu, w nałogach, w bezprawiu, zewnętrznych i wewnętrznych gwałtach, wytłumaczcie je, wpajajcie w miękkie serca jeszcze cnotliwej młodzieży, tej to jedynej nadziei [...]. Niechaj dzieci znają obowiązki człowieka, niechaj się swoją [oswajają - A.Ż.] z powinnościami obywatela, niechaj widzą związki krajów. Z tych okazujcie im potrzeby Polski i ich opatrzenia sposoby ${ }^{41}$.

Charakterystyczna w poglądach Staszica jest więc miłość rodu ludzkiego, przejawiająca się przestrzeganiem przykazania miłości bliźniego, braterską otwartością na wszystkich ludzi oraz utrzymaniem podstawowej równości ludzi w zakresie przywilejów. Pielęgnowanie przyjaznych związków między ludźmi zapobiega licznym nieszczęściom, jakich zawsze doświadczała ludzkość, na przykład wojnie, niewoli, a nawet utracie narodów. W podtrzymaniu ładu i porozumienia światowego szczególną rolę przypisuje filozofom i duchownym, mającym odpowiednie predyspozycje intelektualne i duchowe do ratowania „cierpiącej ludzkości”. Nie wyklucza również udziału działaczy oświatowych, nauczycieli i wychowawców młodego pokolenia w kształtowaniu postawy przychylności wobec ogółu ludzi na świecie, czyli ludzkości (bądź rodu ludzkiego). Choć Staszic nie akcentuje współpracy filozofów i duchownych, uznawanych za apologetów oraz propagatorów postawy przychylności wobec rodu ludzkiego, oraz pedagogów (jako realizatorów procesu wychowania człowieka przychylnego wobec ludzkości), dziś - interpretując jego poglądy - można pozwolić sobie na odejście od dawnego ujęcia separacyjnego działalności tych trzech grup profesjonalistów i zaproponować uzupełnienie jego stanowiska ujęciem konsyliarnym.

\footnotetext{
40 Staszic, Przestrogi..., 251, 252.

41 Tamże, 253.
} 


\section{Podsumowanie}

W dziełach księdza Stanisława Wawrzyńca Staszica, zwłaszcza w Rodzie ludzkim, wybrzmiewa głos prawdy historycznej oraz wrażliwość na cierpienie, ucisk, krzywdę i niesprawiedliwość społeczną, jakiej doświadczały wówczas grupy/stany nieuprzywilejowane, obejmujące znaczną część ludzkości. Warto zapoznać się z tym kompleksowym dziełem (i innymi jego pracami) także z powodu:

- niepodważalnej mądrości autora ujawnionej w ocenie faktów dziejowych (zwłaszcza odnośnie do trwania, „uspołecznienia” i humanizacji ludzkości);

- inspiracji naukowej w nich zawartej;

- szansy rozpoznania treści znaczących nie tylko dla kultury polskiej, lecz także dla ludzkości (problematyka okazuje się cenna w każdym kręgu kulturowym);

- możliwości poznania treści istotnych nie tylko przez ludzi żyjących w XVIII i XIX wieku, ale również współczesnych (problematyka jest równie doniosła i dziś - zatem należy do ponadczasowych);

- bogatych zasobów merytorycznych sprzyjających rozwiązaniu wielu problemów badawczych („odkodowanie” treści zawartych w przyjętej wówczas formie pisemnego przekazu językowego stanowi swoistą „przygodę naukową", „wędrówkę nieodkrytymi lądami i nieutartymi szlakami”, zatem jest rodzajem odkrycia);

- skomplikowanych kolei losu jednego z największych intelektualistów epoki, inicjatora rozwoju gospodarczego i kulturowego naszego kraju, prekursora dynamicznej odbudowy państwowości polskiej, propagatora wzorcowych postaw obywatelskich, a przede wszystkich dobroczyńcy ludzkości.

Barbara Szacka pisze: „Dziwny był los Stanisława Staszica. Za życia prześladowano go oszczerstwami, po śmierci jego pamięć błogosławiły i czciły tłumy tych, których uszczęśliwił" ". Sądzę, że nie tylko stawianie pomników czy upamiętnianie jego imienia nazewnictwem ulic, placów, instytucji (choćby szkół) stanowi przejaw wdzięczności Polaków wobec tego wspaniałego człowieka. Kolejne pokolenia obowiązuje przede wszystkim czytelnictwo, znajomość, a także przekaz kulturowy niezwykle cennej treści dzieł Stanisława Staszica.

Zaprezentowane wnioski stanowią odpowiedzi na sformułowane we wprowadzeniu problemy badawcze. Oto najistotniejsze uogólnienia:

42 Barbara Szacka, Stanisław Staszic (Warszawa: Państwowy Instytut Wydawniczy, 1966), 216. Zob. też Janusz Skodlarski, Nowe spojrzenie na poglady i działalność Stanisława Staszica (Łódź: Wydawnictwo Uniwersytetu Łódzkiego, 2010); Janusz T. Panasiewicz, Człowiek i dzieło. Stanisław Staszic i Towarzystwo Rolnicze Hrubieszowskie (Kraków: Stowarzyszenie Wychowanków Akademii Górniczo-Hutniczej im. Stanisława Staszica w Krakowie, 2015). 
1. Staszic pojmuje ludzkość/ród ludzki niejednoznacznie. W treści analizowanych dzieł, zwłaszcza Rodu ludzkiego, daje się zidentyfikować kilka ujęć rodu ludzkiego - jako zjednoczenia wszystkich ludzi na świecie, sumy pokoleń przeszłych i teraźniejszych (to znaczy ówczesnych), sumy rodów, czyli familii (dziś - rodzin) oraz jako zrzeszenia narodów.

2. Humanizacja ludzkości stanowi proces dziejowy, który przejawia się we wzroście wolności narodowej, na przykład wyzwalaniu się narodów, kształtowaniu ich tożsamości kulturowej, rugowaniu wszelkich przejawów niesprawiedliwości i krzywdy (choćby niewolniczego wyzysku określonych stanów/warstw społecznych czy nierówności wobec prawa).

3. Do najpotężniejszych czynników trwania (bądź przetrwania), „uspołecznienia” oraz humanizacji ludzkości Staszic zaliczył: prawo, obyczajowość, moralność, opinię powszechną, religię, historię, oświatę (szkolnictwo postrzegał jako skuteczny instrument przebudowy społeczeństwa. Dzięki nauczaniu i wychowaniu szkolnictwo różnych szczebli miało kształtować użytecznych obywateli ${ }^{43}$ ).

4. Największą przeszkodę w realizacji procesu humanizacji ludzkości stanowiły: niedoskonałe prawo, brak przejrzystych zasad współżycia społecznego, zaniedbania moralne (nieuczciwość - zwłaszcza oszustwa, kradzieże i grabieże), niewłaściwa religia (oddawanie czci bożkom, wiarołomstwo, bałwochwalstwo), naganna obyczajowość (na przykład związane często ze świętowaniem - i w tym celu wyprawianiem uczt - obżarstwo, opilstwo, rozwiązłość, rozrzutność, kłótliwość, rozbój, zabójstwa), wojny, brak dbałości o ziemię (i jej bogactwa) oraz przemysł, a także wadliwe wychowywanie pokoleń utrwalające przywary ludzkie (w tym wady narodowe).

5. Rola filozofów, duchowieństwa i pedagogów (wówczas - nauczycieli i wychowawców) w procesach przetrwania oraz humanizacji rodu ludzkiego wydaje się niebagatelna. Filozofowie i duchowni są zarazem apologetami ludzkości i popularyzatorami przychylności wobec tej społeczności powszechnej, zaś pedagodzy - realizatorami procesu wychowania kolejnych pokoleń do reprezentowania postawy przychylności wobec rodu ludzkiego. Staszic nie popiera stanowiska zakładającego opozycję/rozziew między stosunkiem do własnego narodu a stosunkiem do rodu ludzkiego. Miłość do narodu i przychylność wobec ludzkości są, w jego przekonaniu, zbliżonymi postawami zarazem obywatelskimi i moralnymi.

6. Korzyść pedagogiczna, jaka płynie z przesłania zawartego $\mathrm{w}$ analizowanych dziełach, zwłaszcza w Rodzie ludzkim, wydaje się oczywista. Trwanie

43 Zob. Adam Winiarz, „Stanisława Staszica koncepcja organizacji szkolnictwa w teorii i praktyce”, Rozprawy z Dziejów Oświaty 45 (2006), 63-83. Zob. też Kalina Bartnicka, „Szkolnictwo wyższe w koncepcjach edukacyjnych Stanisława Staszica”, Rozprawy z Dziejów Oświaty 45 (2006), $35-61$. 
i humanizacja rodu ludzkiego są uzależnione przede wszystkim od właściwego procesu wychowania kolejnych pokoleń, usiłujących doskonalić naturę ludzką na drodze wysiłków wychowawczych, samowychowawczych, autokorektywnych oraz autokreacyjnych.

Streszczenie: Ksiądz Stanisław Wawrzyniec Staszic, choć nie uprawiał filozofii, miał jednak wyraźne przekonania filozoficzne - i dawał im wyraz bezpośrednio bądź pośrednio. Wyjątkowa pozycja Staszica w dziejach Polski sprawia, że warto rekonstruować i twórczo interpretować jego poglądy również z zakresu „filozofii człowieka”, „filozofii wychowania” czy filozofii społecznej. Nie pomijając także innych prac Staszica, w niniejszym artykule przeanalizowano przede wszystkim zawartość merytoryczną Rodu ludzkiego, ponieważ dostrzeżono oryginalność tego dzieła oraz szansę transmisji kapitału kulturowego przeszłości współczesnym i przyszłym odbiorcom kultury. Pozyskanie dzięki metodom hermeneutycznym treści znaczących dla rozwoju społecznego i kulturowego ludzkości stanowi priorytetowy cel poznawczy autorki artykułu. Zatem problemy badawcze zostały sformułowane następująco: Jak Staszic pojmuje ludzkość/ród ludzki (lub jak definiuje ten termin)?; Czy, w jego przekonaniu, jest możliwa humanizacja ludzkości?; Jeśli tak, to jak zachodzi oraz jak się przejawia?; Jakie daje się wyliczyć czynniki trwania (względnie przetrwania) oraz humanizacji ludzkości?; Co stanowiło w dziejach ludzkości, w jego opinii, największe przeszkody w realizacji tych procesów?; Jaką rolę przypisuje w tym zakresie filozofom, duchowieństwu i pedagogom?; Jakie przesłanie pedagogiczne dla współczesnych pokoleń udaje się odczytać w wyniku analizy i interpretacji treści dzieł Staszica? Końcową część artykułu stanowią wnioski zawierające zwięzłe odpowiedzi na problemy badawcze.

Słowa kluczowe: ludzkość, ród ludzki, Stanisław Staszic, Oświecenie, godność, rozum, wola, wolność

\section{Bibliografia}

Bartnicka, Kalina. „Szkolnictwo wyższe w koncepcjach edukacyjnych Stanisława Staszica”. Rozprawy z Dziejów Oświaty 45 (2006), 35-61.

Chyra-Rolicz, Zofia. Stanisław Staszic. Warszawa: Państwowe Wydawnictwo Naukowe, 1980.

Cieszkowski, Stanisław. Stanisław Staszic: filantrop, mąż stanu i uczony ur. 1755-1826. Zarys biograficzny w setna rocznicę zgonu. Warszawa: Biblioteka Domu Polskiego, 1925.

Grondin, Jean. Wprowadzenie do hermeneutyki filozoficznej, tłum. Leszek Łysień. Kraków: Wydawnictwo WAM, 2007.

Jadacki, Jacek. „O poglądach filozoficznych Stanisława Staszica”. Rocznik Towarzystwa Naukowego Warszawskiego 68 (2005), 28-38.

Kostkiewicz, Janina. Wychowanie do wolności wyboru. Ponadczasowy wymiar pedagogiki Fryderyka Wilhelma Foerstera. Kraków: Oficyna Wydawnicza „Impuls”, 2008.

Milerski, Bogusław. Hermeneutyka pedagogiczna. Perspektywy pedagogiki religii. Warszawa: Wydawnictwo Naukowe ChAT, 2011.

Molik, Witold. Stanisław Staszic (1755-1826). Poznań: Krajowa Agencja Wydawnicza, 1980. 
Panasiewicz, Janusz Tadeusz. Człowiek i dzieło. Stanisław Staszic i Towarzystwo Rolnicze Hrubieszowskie. Kraków: Stowarzyszenie Wychowanków Akademii Górniczo-Hutniczej im. Stanisława Staszica w Krakowie, 2015.

Podgórski, Grzegorz. „Od wydawcy”. W: Stanisław Staszic, Ród ludzki, www.powrotdonatury.net. pl/...Ród\%20ludzki\%20...\%20Staszic.pdf/download.html (dostęp: 18.05.2019).

Skodlarski, Janusz. Nowe spojrzenie na poglady i działalność Stanisława Staszica. Łódź: Wydawnictwo Uniwersytetu Łódzkiego, 2010.

Stanisław Staszic. Geologia - górnictwo - hutnictwo, red. Antoni Stanisław Kleczkowski. Warszawa: Wydawnictwa Geologiczne, 1979.

Staszic, Stanisław. Przestrogi dla Polski, oprac. Stefan Czarnowski. Wrocław: Zakład Narodowy im. Ossolińskich - Wydawnictwo, 2003.

Staszic, Stanisław. Ród ludzki, t. 1-3. Warszawa: Państwowe Wydawnictwo Naukowe, 1959.

Staszic, Stanisław. Ród ludzki, www.powrotdonatury.net.pl/...Ród\%20ludzki\%20...\%20Staszic.pdf/ download.html (dostęp: 18.05.2019).

Staszic, Stanisław. Uwagi nad życiem Jana Zamoyskiego. Wrocław: Zakład Narodowy im. Ossolińskich - Wydawnictwo, 2005.

Staszic, Stanisław. Uwagi nad życiem Jana Zamoyskiego, wydanie krytyczne przygotował i wstępem zaopatrzył Stefan Czarnowski. Kraków: Krakowska Spółka Wydawnicza, 1926.

Stępień, Antoni. Wstęp do filozofii. Lublin: Towarzystwo Naukowe Katolickiego Uniwersytetu Lubelskiego, 2001.

Suchodolski, Bogdan. „Wstęp”. W: Stanisław Staszic. Być narodowi użytecznym, wybór Bogdan Suchodolski, 9-23. Wrocław: Wydawnictwo Stronnictwa Demokratycznego „Epoka”, 1985.

Szacka, Barbara. Stanisław Staszic. Warszawa: Państwowy Instytut Wydawniczy, 1966.

Wartość i sens. Aksjologiczne aspekty teorii interpretacji, red. Andrzej Tyszczyk, Edward Fiały, Ryszard Zajączkowski. Lublin: Wydawnictwo Katolickiego Uniwersytetu Lubelskiego, 2003.

Winiarz, Adam. „Stanisława Staszica koncepcja organizacji szkolnictwa w teorii i praktyce”. Rozprawy z Dziejów Oświaty 45 (2006), 63-83.

Wójcik, Zbigniew. Stanisław Staszic. Organizator nauki i gospodarki. Kraków: Stowarzyszenie Wychowanków Akademii Górniczo-Hutniczej im. Stanisława Staszica w Krakowie, 1999.

Żywczok, Alicja. „»Ludzkość« - zapomniana kategoria nauki. Batalia o przypomnienie i włączenie terminu do programów edukacyjnych". W: Pedagogika filozoficzna, t. 7: Uniwersalizm i regionalizm pedagogiki filozoficznej, red. Sławomir Sztobryn, Dariusz Stępkowski, 17-29. Łódź: Wydawnictwo Naukowe TPF „Chowanna”, 2017. 